\title{
Mitigation of Drought Stress Effects on Pepper Seedlings by Exogenous Methylamine Application
}

\author{
Ertan Yildirim ${ }^{1 *}$, Melek Ekinci ${ }^{1}$, Raziye Kul ${ }^{1}$, Metin Turan², Ayla Gür ${ }^{1}$ \\ ${ }^{1}$ Atatürk University, Faculty of Agriculture, Department of Horticulture, Erzurum-Turkey \\ 2 Yeditepe University, Faculty of Engineering and Architecture, Department of Genetics and \\ Bioengineering, Kayısdagı, Istanbul-Turkey \\ *ertanyil@atauni.edu.tr
}

\section{Keywords: Irrigation, Pepper, Growth, Antioxidant, Methylamine}

\begin{abstract}
The study was conducted to determine effects of a new synthesis of methylamine on the plant growth, physiological and biochemical characteristics in pepper under drought stress. There were four irrigation levels [full irrigation (100\%) (I0), 80\% (I1), 60\% (I2) and 40\% (I3)] and two methylamine (MA) treatments $(0,2.5 \mathrm{mM})$. At the end of the study, it was observed that there were significant differences between applications and levels. Effects of MA treatments on plant growth (plant height, stem diameter, fresh, dry weight etc.), plant physiological and biochemical parameters [tissue electrical conductivity (TEC), tissue relative water content (TRWC), hydrogen peroxide $\left(\mathrm{H}_{2} \mathrm{O}_{2}\right)$, malondialdehyde (MDA), proline, antioxidant enzyme activity], and plant nutrient element content of pepper seedlings under different irrigation levels were significantly important. The results of the study showed that the drought stress conditions negatively affected the plant growth, increased the content of TEC, $\mathrm{H}_{2} \mathrm{O}_{2}$ and MDA, and decreased the TRWC and plant mineral content in pepper. However, MA application improved plant growth and decreased TEC, $\mathrm{H}_{2} \mathrm{O}_{2}$ and MDA content compared to control in pepper under drought conditions. MA treated plants at $\mathrm{I} 3 \mathrm{had}$ higher shoot fresh weight and shoot dry weight than non-treated plants by 12 and $20 \%$, respectively. In conclusion, MA application could mitigate the deleterious effects of the drought stress on the pepper seedlings.
\end{abstract}

\section{Introduction}

The decrease in water resources has reached to a level that negatively affects the sustainable life as well as the damage caused to the environment. Due to the major environmental stress factors that limit crops productivity, it is becoming increasingly difficult to find suitable areas for plant production. Plants encounter various stress conditions throughout their life cycle. Drought stress is one of the most common abiotic stresses affecting growth and yield, and it has been determined that it activates many protection systems at physiological, biochemical and molecular levels in plants. Drought prevents the growth of the plant as a result of the effect of decreasing the division, growth and turgor pressure of the cells. Drought conditions also negatively affect the transpiration, which may lead to decrease of mineral material intake and decrease of growth rate [1-3].

Water is one of the indispensable growth factors for successful vegetable growing. Vegetables need water for normal vegetative and generative growth and development. Short-term water stress of vegetable crops causes them to close stomata to reduce water loss from the leaves. However, in the event of a long-term drought, irreversible damage occurs in plants and eventually death occurs [4].

There are various organic osmolytes and other compatible solutes. These are sugars (e.g. trehalose), polyols (glycerol, inositols, sorbitol, etc.), amino acids (glycine, proline, taurine, etc.), methylamines [such as $\mathrm{N}$ - trimethylamine oxide (TMAO) and glycine betaine] [5]. Osmolites like methyl ammonium compounds are small molecules that accumulate by cells to prevent denaturing stresses. These osmolites help protect the structural and functional integrity of the macromolecules in animals, protecting cells from hostile stress [6].

Polyamines are small ubiquitous poly-cations involved in many plant growth and development processes and are well known for their anti-aging and anti-stress effects due to their acid neutralization and antioxidant properties as well as their membrane and cell wall stabilization 
capabilities. Polyamines in plants are effective in growth and development events such as cell division, root formation, adventitious shoot formation, flower formation, fruit ripening and embryo formation in tissue culture [7]. Polyamines have been suggested to play an important role in controlling defense responses to various environmental stresses including metal toxicity [8], oxidative stress [9], drought [10], salinity [11] and low temperature stress [12, 13] in plants. However, to our best knowledge, there is no information on the effects of methylamine on plant growth, some physiological and biochemical properties of pepper seedlings under drought stress in plants.

Irrigation is essential for the production of peppers since pepper is considered as one of the most sensitive vegetable species to water stress [14-16]. This study was conducted to determine the effects of methylamine on plant growth, some physiological and biochemical properties of pepper seedlings under different irrigation regimes.

\section{Materials and Methods}

This study was carried out under controlled greenhouse conditions at Atatürk University in 2017. Pepper (Capsicum annum L. cv. Menderes K1l Ac1) was used as plant material. Sterilized seeds were sown to $1 \mathrm{~cm}$ deep in 216-celled trays filled with peat: perlite (3:1 v: v). After 30 days from planting, healthy seedlings were transferred to pots with mixture of garden soil and sand (2: 1, v:v). The soil used in the experiment had $26.3 \%$ sand, $33.2 \%$ silt, and $40.5 \%$ clay. Soil chemical

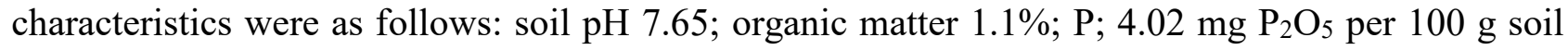
and $\mathrm{K} 111 \mathrm{mg} \mathrm{K} \mathrm{K}_{2} \mathrm{O}$ per $100 \mathrm{~g}$ soil. The weight of all the pots was adjusted to be $2,300 \mathrm{~g}$. The pots were randomly put on the benches in the greenhouse. The temperature and humidity of the greenhouse were monitored daily. The average minimum temperature was $18.7^{\circ} \mathrm{C}$ and the average maximum temperature was $34.1^{\circ} \mathrm{C}$ and the humidity was $55 \%$.

Methylamine (MA) used in the study is a new synthesis polymer developed by Prof. Dr. Metin Turan who works in Department of Genetics and Bioengineering at Yeditepe University. A new methyl amine molecule were synthesized from the composition of sarcosine, trimethylamine N-oxide (TMAO), and betaine as methyl-amine, which exact formulation of the synthesis composition has not been reported since it has a patent potential (Fig. 1). MA solutions were prepared at levels of 0 (control) and 2,5 $\mathrm{mM}$ in pure water. We chose this concentration $(2,5 \mathrm{mM})$ because it was the best concentration in another project we made in squash under drought stress. The roots of seedlings were immersed into the corresponding solutions of MA before transplanting for 5 minutes. One week after transplanting, $200 \mathrm{ml}$ of the same solutions were drenched to roots of the plants.

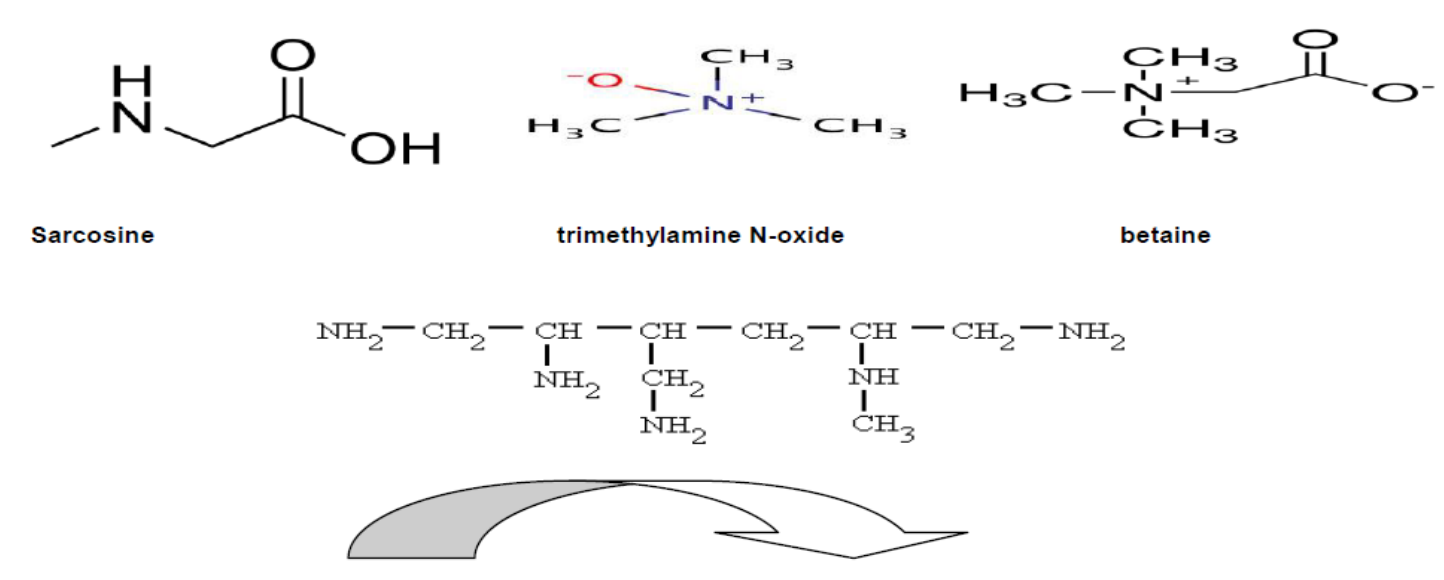

$X$ SENTEZ

Figure 1. A new methyl amine molecule were synthesized from the composition of sarcosine, trimethylamine N-oxide (TMAO), and betaine as methyl-amine 
The irrigation water dose to be given to the plants was calculated based on the volume of moisture content in the pots by means of a portable moisture meter (HH2 Moisture Meter, WET Sensor, Delta-T Devices, Cambridge, England). In order to realize the irrigation applications, firstly the calibration of the moisture meter was done according to the soil material used in the experiment, and the specific amount of volumetric moisture kept by the media at field capacity was determined. Full irrigation (100\%) (I0) was applied in the amount of soil moisture to reach the field capacity. In the other three irrigation levels, which were aimed to be seen drought effects, irrigation was done in $80 \%$ (I1), 60\% (I2) and 40\% (I3) of field capacity. Scheduled irrigations were initiated ten days after transplanting. After 50 days from planting, the plants were cut from the soil surface, and the roots from the pots were washed freshly.

After 50 days of seedling transplanting, plant height, number of leaves, stem diameter, leaf area, tissue relative water content (TRWC) and tissue electric conductance (TEC) were measured. Plant samples were taken for dry weights and fresh samples kept for chemical analysis at $-80{ }^{\circ} \mathrm{C}$.

The plant leaf area in each application was determined using a leaf area meter (CI-202 Portable Laser Leaf Area Meter by CID Bio-Science, Inc. 1554 NE 3rd Avenue Camas, WA, USA).

TEC and TRWC measurements were performed on leaf samples taken from intact plants [17].

Assays of antioxidant enzyme activity were performed according to Agarwal and Pandey [18], Angelini et al. [19], Gong et al. [20] and Yordanova et al. [21].

To determine the mineral concentrations of pepper leaves was used an inductively coupled plasma spectrophotometer (Optima 2100 DV; Perkin-Elmer, Shelton, CT) [22, 23, 24].

The experimental design was hierarchical with respect to two factors arranged in a completely randomized design with four replications per treatment and 5 plants per replicate. The first factor (irrigation levels) had four levels $(100 \%, 80,60$ and 40), and the second one (MA levels) had two levels $(0,2.5 \mathrm{mM})$. Data was subjected to analysis of variance (two-way ANOVA) to compare the effects of salt stress and irrigation level treatments. Means were separated by Duncan's multiple range tests.

\section{Results and Discussion}

The effect of irrigation levels and MA application on the growth of pepper seedlings was found to be important $(\mathrm{p}<0.001)$. Water deficit conditions negatively affected the growth of pepper and decreased the plant height, stem diameter, leaf number, leaf area, shoot and root fresh and dry weight. The least values were observed at I3 irrigation in both 0 and 2,5 mM MA application. I3 treatment decreased the plant height, stem diameter, leaf number, leaf area, shoot fresh weight, shoot dry weight, root fresh weight and root dry weight by 53,42, 42, 60, 78, 79, 54 and 92\%, respectively, as compared to the control in non-MA treatment condition. However, MA treatment improved the parameters investigated compared to non-MA treatment (Tables 1,2). In parallel with the findings of our study, there are many studies reporting that drought stress adversely affects plant growth in pepper $[25,26,27]$.

Previous studies have shown that polyamine applications such as Putresin (Put), Spermidin (Spd) and Spermin (Spr) have a positive effect on plant growth in abiotic stress conditions [28, 29, $30]$. It is reported that polyamines cause mitosis in the cell, leading to cell division and subsequent cell growth $[31,32,33]$. Polyamines play an important role in many other physiological processes such as embryo formation, organ formation, flower formation and development, fruit development and maturation, leaf senescence, biotic and abiotic stress. It is also found in all internal structures of the plant cell, or even in the nucleus, in one or more vital processes [34-41]. Exogenous polyamine treatments have reported to improve plant tolerance against to abiotic stress conditions [42, 43]. In fact, studies have shown that exogenous Put and Spd treatments enhanced drought tolerance in several crops $[44,46]$. Studies in different plant species have been described as polyamine accumulation in plants as a response to salinity, drought, cold, ozone, hot, UV, mechanical injury, heavy metal toxicity, herbicide applications and many other environmental events [38, 40, 13, 45]. 
Table 1. The effect of drought and MA treatments on the plant height, stem diameter, leaf number and leaf area in pepper

\begin{tabular}{llllll}
\hline Application & Irrigation & $\begin{array}{c}\text { Plant height } \\
(\mathbf{c m})\end{array}$ & $\begin{array}{c}\text { Stem } \\
\text { diameter } \\
(\mathbf{m m})\end{array}$ & $\begin{array}{c}\text { Leaf } \\
\text { number }\end{array}$ & $\begin{array}{c}\text { Leaf area } \\
\text { (cm } / \text { plant) }\end{array}$ \\
\hline $\mathbf{0}$ & $\mathbf{I 0}$ & $16.30 \mathrm{~b} * * *$ & $3.10 \mathrm{c}^{* * *}$ & $17.47 \mathrm{~b} * * *$ & $4.66 \mathrm{a}^{* * *}$ \\
& $\mathbf{I 1}$ & $12.07 \mathrm{~d}$ & $2.72 \mathrm{~d}$ & $14.87 \mathrm{~d}$ & $3.55 \mathrm{c}$ \\
& $\mathbf{I 2}$ & $9.53 \mathrm{e}$ & $2.29 \mathrm{e}$ & $11.47 \mathrm{f}$ & $2.52 \mathrm{~d}$ \\
$\mathbf{M A}$ & $\mathbf{I 3}$ & $7.60 \mathrm{~g}$ & $1.79 \mathrm{f}$ & $10.17 \mathrm{~g}$ & $1.89 \mathrm{e}$ \\
& $\mathbf{I 0}$ & $19.47 \mathrm{a}$ & $3.47 \mathrm{a}$ & $18.53 \mathrm{a}$ & $4.84 \mathrm{a}$ \\
& $\mathbf{I 1}$ & $14.13 \mathrm{c}$ & $3.29 \mathrm{~b}$ & $16.14 \mathrm{c}$ & $4.12 \mathrm{~b}$ \\
& $\mathbf{I 2}$ & $10.01 \mathrm{e}$ & $2.60 \mathrm{~d}$ & $13.47 \mathrm{e}$ & $3.40 \mathrm{c}$ \\
Irrigation & $\mathbf{I 3}$ & $8.40 \mathrm{f}$ & $2.30 \mathrm{e}$ & $11.27 \mathrm{f}$ & $2.11 \mathrm{e}$ \\
Application & & $* * *$ & $* * *$ & $* * *$ & $* * *$ \\
Application & $* * *$ & $* * *$ & $* * *$ & $* *$ \\
Irrigation & & $* * *$ & $*$ & $* *$ & $* *$ \\
\hline
\end{tabular}

Data followed by a different letter in column were significantly different $(\mathrm{P} \leq 0.001)$ according to the DMRT

Table 2. The effect of drought and MA treatments on shoot fresh weight, shoot dry weight, root fresh weight and root dry weight in pepper

\begin{tabular}{|c|c|c|c|c|c|}
\hline Application & Irrigation & $\begin{array}{l}\text { Shoot fresh } \\
\text { weight } \\
\text { (g/plant) }\end{array}$ & $\begin{array}{l}\text { Shoot dry } \\
\text { weight } \\
\text { (g/plant) }\end{array}$ & $\begin{array}{l}\text { Root fresh } \\
\text { weight } \\
\text { (g/plant) }\end{array}$ & $\begin{array}{l}\text { Root dry } \\
\text { weight } \\
\text { (g/plant) }\end{array}$ \\
\hline \multirow[t]{4}{*}{$\mathbf{0}$} & I0 & $3.24 \mathrm{~b}^{* * *}$ & $0.19 \mathrm{~b}^{* * *}$ & $1.45 \mathrm{c}^{* * *}$ & $0.122 \mathrm{a}^{* * *}$ \\
\hline & I1 & $1.82 \mathrm{~d}$ & $0.11 \mathrm{~d}$ & $1.32 \mathrm{~d}$ & $0.075 \mathrm{c}$ \\
\hline & $\mathbf{I 2}$ & $0.91 \mathrm{f}$ & $0.05 \mathrm{e}$ & $0.71 \mathrm{f}$ & $0.010 \mathrm{e}$ \\
\hline & $\mathbf{I 3}$ & $0.72 \mathrm{~g}$ & $0.04 \mathrm{e}$ & $0.67 \mathrm{f}$ & $0.009 \mathrm{e}$ \\
\hline \multirow[t]{4}{*}{ MA } & I0 & $4.07 \mathrm{a}$ & $0.21 \mathrm{a}$ & $1.86 \mathrm{a}$ & $0.119 \mathrm{ab}$ \\
\hline & I1 & $2.47 \mathrm{c}$ & $0.15 \mathrm{c}$ & $1.54 \mathrm{~b}$ & $0.100 \mathrm{~b}$ \\
\hline & I2 & $1.64 \mathrm{e}$ & $0.09 \mathrm{~d}$ & $1.09 \mathrm{e}$ & $0.040 \mathrm{~d}$ \\
\hline & I3 & $0.82 \mathrm{fg}$ & $0.04 \mathrm{e}$ & $0.66 \mathrm{f}$ & $0.008 \mathrm{e}$ \\
\hline Irrigation & & $* * *$ & $* * *$ & $* * *$ & $* * *$ \\
\hline Application & & $* * *$ & $* * *$ & $* * *$ & $*$ \\
\hline $\begin{array}{l}\text { Application } \\
\text { Irrigation }\end{array}$ & & $* * *$ & $*$ & $* * *$ & $*$ \\
\hline
\end{tabular}

Data followed by a different letter in column were significantly different $(\mathrm{P} \leq 0.001)$ according to the DMRT

Drought stress caused the membrane damage in pepper which increase the TEC value (Table 3 ). Similarly, drought conditions caused an increase in $\mathrm{H}_{2} \mathrm{O}_{2}$ and MDA contents of pepper plants (Table 3). The drought led to a decrease in the TRWC value (Table 3). Drought stress also affects the stomata in the plant. A decrease in stoma conductivity is caused by an increase in the leaf temperature and damage to the membrane systems due to a decrease in the leaf water content in the leaves [46, 2]. The production of reactive oxygen species (ROS), such as superoxide and $\mathrm{H}_{2} \mathrm{O}_{2}$, is considered the most common response in plants under abiotic stress. High ROS levels result in protein and lipid peroxidation, chlorophyll deterioration and programmed cell death [47]. In our study, it was determined that MA applications reduced the TEC, MDA and $\mathrm{H}_{2} \mathrm{O}_{2}$, content in pepper under water deficit conditions compared to untreated control plants (Table 3).

In previous studies, it has been reported that polyamine applications protect the cell membrane, trigger the expression of osmotic response genes, reverse stress-induced growth inhibition, reduce $\mathrm{H}_{2} \mathrm{O}_{2}$, and increase the activity of antioxidant enzymes under stress conditions [48, 49, 50]. Polyamines are also reported to play a role in the regulation of $\mathrm{H}_{2} \mathrm{O}_{2}$ production in plants. Spd 
application has been reported to increase the tolerance to drought by controlling the production of $\mathrm{H}_{2} \mathrm{O}_{2}$ and the expression of antioxidant-related genes [50]. Shi et al. [51] found that polyamine applications significantly alleviated the effects of drought and salt stresses, and significantly increased antioxidant enzymes and several other stress-related proteins. The role of polyamines in reducing the adverse effects of stress conditions can probably be due to their direct interaction with membranes, reduction of oxidant activity, functioning as a compatible osmolite [52].

In our study, the effect of MA application on proline content in pepper grown at different irrigation levels was found to be significant (Table 3 ). The greatest proline content was found in I2 and I3 irrigation levels. Proline is the osmolite amino acid that provides osmotic adjustment [53]. In response to water deficiency stress, plants accumulate large amounts of proline [54, 55]. Krasensky and Jonak [58] suggested a strong relationship between proline content and stress tolerance in plants. Khan et al. [56] determined higher proline content in cabbage seedlings grown under drought stress. In other studies, it has been emphasized that externally applied polyamines may increase proline, which contributes to the positive effects of stress [11,57].

Table 3. The effect of drought and MA treatments on TEC, TRWC, $\mathrm{H}_{2} \mathrm{O}_{2}, \mathrm{MDA}$ and prolin content in pepper

\begin{tabular}{|c|c|c|c|c|c|c|}
\hline Application & Irrigation & $\begin{array}{l}\text { TEC } \\
(\%)\end{array}$ & $\begin{array}{l}\text { LRWC } \\
(\%)\end{array}$ & $\begin{array}{l}\mathbf{H}_{2} \mathbf{O}_{2} \\
(\mathrm{mmol} / \mathrm{kg})\end{array}$ & $\begin{array}{l}\text { MDA } \\
(\mathrm{mmol} / \mathrm{kg})\end{array}$ & $\begin{array}{l}\text { Prolin } \\
(\mathrm{mmol} / \mathrm{kg})\end{array}$ \\
\hline \multirow[t]{4}{*}{$\mathbf{0}$} & I0 & $11.88 \mathrm{e}^{* * *}$ & $70.83 \mathrm{a}^{* * *}$ & $8.82 \mathrm{f}^{* * *}$ & $4.32 \mathrm{f}^{* * *}$ & $496.00 \mathrm{bc}^{* * *}$ \\
\hline & I1 & $23.58 \mathrm{c}$ & $58.86 \mathrm{c}$ & $11.71 \mathrm{a}$ & $4.81 \mathrm{de}$ & $491.33 \mathrm{bc}$ \\
\hline & I2 & $24.88 \mathrm{~b}$ & $46.22 \mathrm{e}$ & $11.41 \mathrm{~b}$ & $5.38 \mathrm{~b}$ & $556.33 \mathrm{a}$ \\
\hline & I3 & $26.55 \mathrm{a}$ & $39.61 \mathrm{f}$ & $11.94 \mathrm{a}$ & $5.80 \mathrm{a}$ & $539.67 \mathrm{a}$ \\
\hline \multirow[t]{4}{*}{ MA } & I0 & $11.75 \mathrm{e}$ & $68.19 \mathrm{a}$ & $8.40 \mathrm{~g}$ & $4.41 \mathrm{f}$ & $472.67 \mathrm{~cd}$ \\
\hline & I1 & $21.67 \mathrm{~d}$ & $63.58 \mathrm{~b}$ & $9.32 \mathrm{e}$ & $4.63 \mathrm{e}$ & $473.33 \mathrm{~cd}$ \\
\hline & I2 & $21.33 \mathrm{~d}$ & $54.33 \mathrm{~d}$ & $10.17 \mathrm{~d}$ & $4.92 \mathrm{~d}$ & $454.33 \mathrm{~d}$ \\
\hline & I3 & $24.50 \mathrm{~b}$ & $44.62 \mathrm{e}$ & $10.53 \mathrm{c}$ & $5.18 \mathrm{c}$ & $501.67 \mathrm{~b}$ \\
\hline Irrigation & & $* * *$ & $* * *$ & $* * *$ & $* * *$ & $* * *$ \\
\hline Application & & $* * *$ & $* * *$ & $* * *$ & $* * *$ & $* * *$ \\
\hline $\begin{array}{l}\text { Application } \\
\text { Irrigation }\end{array}$ & & $* * *$ & $* * *$ & $* * *$ & $* * *$ & $* * *$ \\
\hline
\end{tabular}

Data followed by a different letter in column were significantly different $(\mathrm{P} \leq 0.001)$ according to the DMRT

CAT, POD and SOD activity was significantly $(\mathrm{p}<0.001)$ affected by irrigation levels and MA applications (Fig. 2). Antioxidant defense systems play a fundamental role in plant tolerance of oxidative damage. Water deficit conditions generally caused the increment of antioxidant activity. In addition to that, MA treatments further increased the CAT, POD and SOD activity compared to the non-MA treatments. The greatest activities were obtained from I 2 at both MA treatments. Similarly, many studies pointed out that drought stress conditions elevated antioxidant enzyme (e.g. CAT, SOD, POT, APX, GR) activities in various crops [58, 59, 60]. Li et al. [61, 62] reported exogenous polyamine treatments enhanced SOD, CAT, and APX activity in clover under water deficit conditions. Furthermore, exogenous polyamine spraying significantly affected the antioxidant enzyme activity in lettuce under drought stress [63]. It has been shown in several studies that the polyamines applied externally also provide an increase in the polyamine levels and contribute to the protective effects of the polyamines $[64,11]$. 


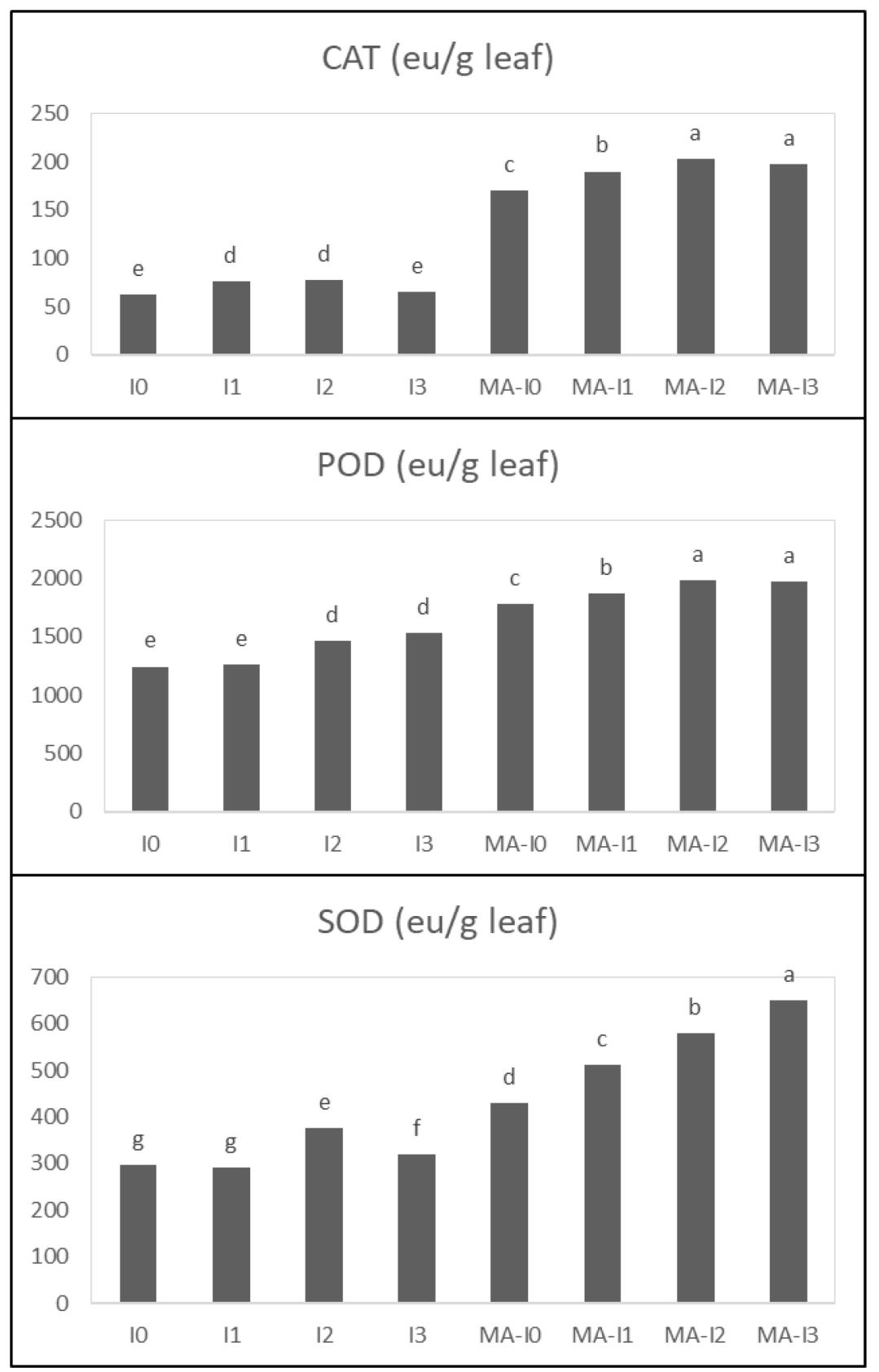

Figure 2. The effect of drought and MA treatments on CAT, POD and SOD activity in pepper. The different letters on the bars indicate the significant difference at 0.001 level according to the DMRT

Plant nutrient element content of pepper leaves decreased as drought severity increased. However, MA-treated plant had greater values than the control plants in regard to all investigated element content. There were negative correlations between the drought stress and mineral content of pepper levels (Figs. 3 and 4). Reducing the presence of water due to drought cause limited amounts of nutrient uptake and reduced tissue concentrations in plant. A significant impact of the water deficit is the acquisition of nutrients by the root and the transfer to the shoots [65]. Polyamines have been shown to increase the plant nutrient uptake in soilless culture [66]. Youssef et al. [67] reported that polyamine treatments enhanced metabolic processes by improving root efficiency, so absorbing macro elements from soil.

MA has been reported to help protect the structural and functional integrity of the macromolecules in animals, protecting cells from hostile stress [6]. The MAs are osmolites which stabilize protein structure, and they modulate the water molecules tightly and result in the exclusion of osmolite from the layers of hydration of the peptide [68].

Polyamines in plants are effective in growth and development events such as cell division, root formation, adventitious shoot formation, flower formation, fruit ripening and embryo formation in 
tissue culture. The increase in the levels of polyamines especially occurs in response to water deficiency, salt stress, aging and environmental stresses [69]. Earlier studies reported that exogenous polyamine treatments could trigger physiological processes and stimulated the osmotic adjustment substances production. This situation might mitigate the negative effects of drought stress on plant growth and improve the quality and amount of some bioactive compounds [70, 71, 72].

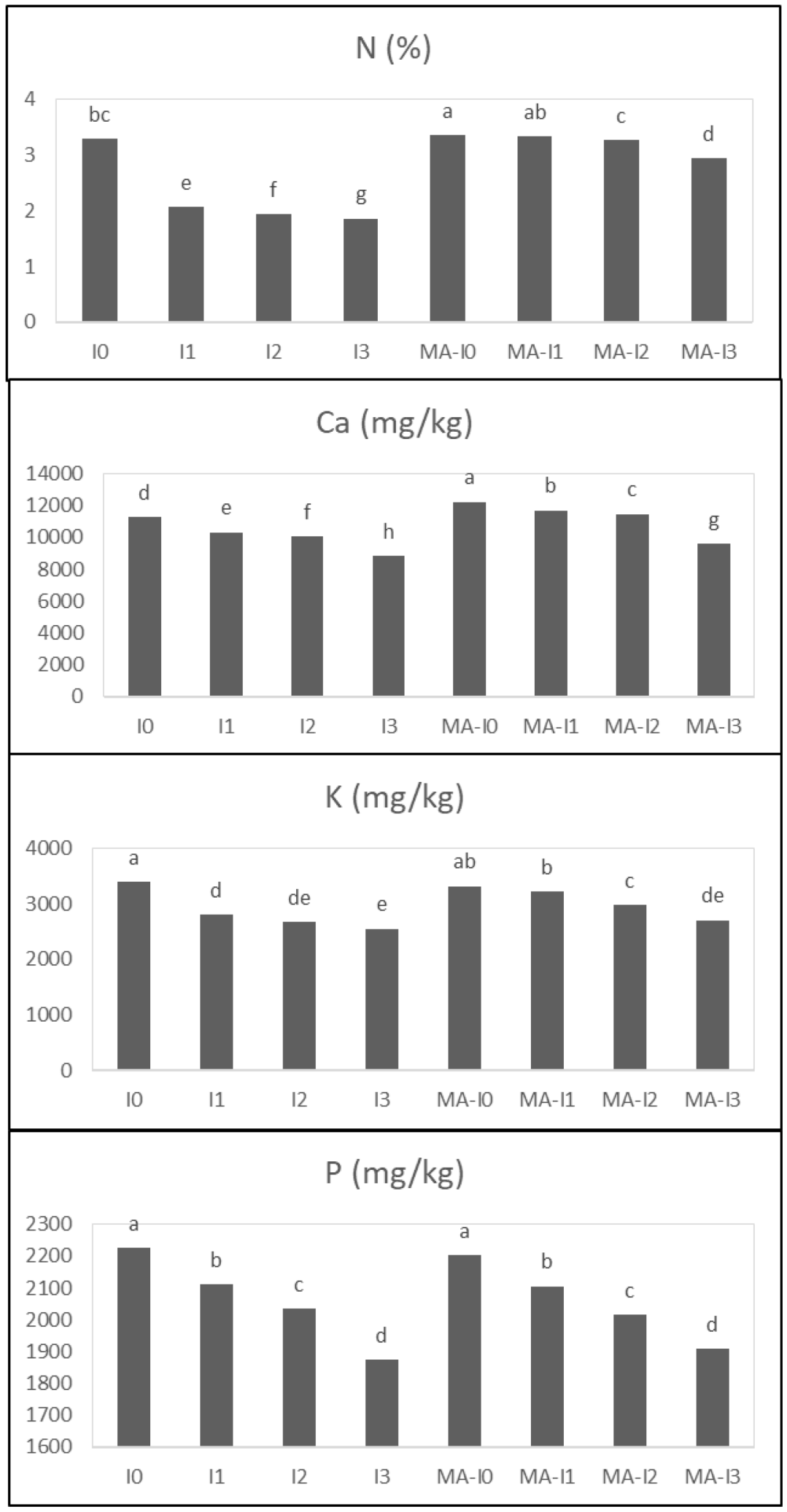

Figure 3. The effect of drought and MA treatments on $\mathrm{N}, \mathrm{Ca}, \mathrm{K}$ and $\mathrm{P}$ content in pepper. The different letters on the bars indicate the significant difference at 0.001 level according to the DMRT 


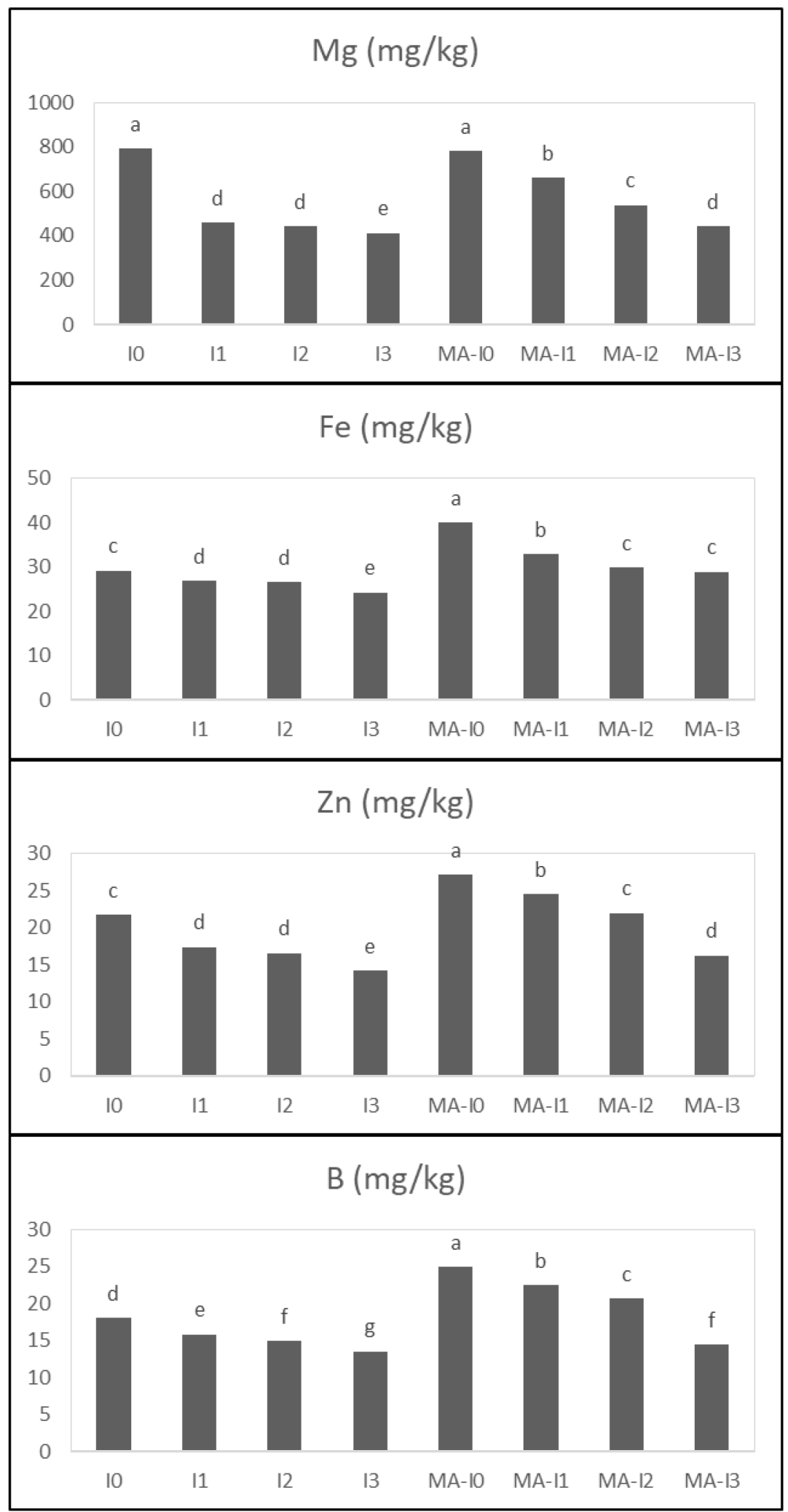

Figure 4. The effect of drought and MA treatments on $\mathrm{Mg}, \mathrm{Fe}, \mathrm{Zn}$ and $\mathrm{B}$ content in pepper. The different letters on the bars indicate the significant difference at 0.001 level according to the DMRT

\section{Conclusion}

As a result of the study, plant growth characteristics of pepper were slightly decreased at lowstress levels, but decreased drastically at the highest stress levels. The drought stress conditions negatively affected the plant growth, increased the content of TEC, $\mathrm{H}_{2} \mathrm{O}_{2}$ and MDA, and decreased the TRWC and plant mineral content in pepper. However, MA application improved plant growth 
and decreased TEC, $\mathrm{H}_{2} \mathrm{O}_{2}$ and MDA content compared to control in pepper under drought conditions. In conclusion, external MA applications could alleviate the harmful effects of drought stress. MA applications may have this positive effect by increasing the TRWC, antioxidant activity and plant nutrient element content, and decreasing TEC, MDA and $\mathrm{H}_{2} \mathrm{O}_{2}$ in pepper.

\section{Conflict of Interest}

The authors declare that there is no conflict of interest.

\section{Acknowledgements}

We are grateful to Atatürk University for its facilities.

\section{References}

[1] U. Sahin et al., Ameliorative effects of plant growth promoting bacteria on water-yield relationships, growth, and nutrient uptake of lettuce plants under different irrigation levels, Hortsci. 50(9) (2015) 1379-1386.

[2] S. Ors, et al., Changes in gas exchange capacity and selected physiological properties of squash seedlings (Cucurbita pepo L.) under well-watered and drought stress conditions, Arch. Agron. Soil Sci. 62(12) (2016) 1700-1710.

[3] U. Sahin et al., Effects of individual and combined effects of salinity and drought on physiological, nutritional and biochemical properties of cabbage (Brassica oleracea var. capitata). Scie. Hortic. 240(20) (2018) 196-204.

[4] M. Ekinci et al., Responses to the irrigation water amount of spinach supplemented with organic amendment in greenhouse conditions. Commun. Soil Sci. Plant Anal. 46(3) (2015) 327-342

[5] P.H. Yancey, Organic osmolytes as compatible, metabolic and counteracting cytoprotectants in high osmolarity and other stresses. The Journal of Experimental Biology 208 (2005) 28192830 .

[6] M.Y. Bhat, L.R. Singh, T.A. Dar, Trimethylamine N-oxide abolishes the chaperone activity of $\alpha$-casein: an intrinsically disordered protein. Scientific Reports. 7 (2017) 6572.

[7] H. Zhao, H. Yang, Exogenous polyamines alleviate the lipid peroxidation induced by cadmium chloride stress in Malus hupehensis Rehd. Scientia Hortic. 116 (2008) 442-447.

[8] M.D. Groppa, M.P. Benavides, M.L. Tomaro, Polyamine metabolism in sunflower and wheat leaf discs under cadmium or copper stress. Plant Sci. 161 (2003) 481-488.

[9] J. Rider et al., Spermine and spermidine mediate protection against oxidative damage caused by hydrogen peroxide. Amino acids. 33(2) (2007) 231-240.

[10] K. Yamaguchi et al., A protective role for the polyamine spermine against drought stress in Arabidopsis. Biochem. Biophy. Res. Commun. 352 (2007) 486-490.

[11] J.J. Duan et al., Exogenous spermidine affects polyamine metabolism in salinity-stressed Cucumis sativus roots and enhances short-term salinity tolerance. J. Plant Physiol. 165 (2008) 1620-1635.

[12] J.C. Cuevas et al., Putrescine is involved in Arabidopsis freezing tolerance and cold acclimation by regulating ABA levels in response to low temperature. Plant Physiol. 148 (2008) 1094-1105.

[13] M.D. Groppa, M.P. Benavides, Polyamines and abiotic stress: recent advances, Amino Acids, 34 (2008) 35-45. 
[14] J. Doorenbos, A.H. Kassam, Yield response to water, irrigation and drainage, FAO, Rome, Italy, 1986, Paper 33.

[15] N. Katterji, M. Mastrorili, A. Hamdy, Effect of stress at different growth stage on pepper yield. Acta Hortic. 335 (1993) 165-171.

[16] R.E. Jaimez et al., Effects of water deficit on the dynamics of flowering and fruit production in capsicum. Chinese Jacque in a tropical semiarid region of Venezuela. J. Agron. Crop Sci. 185 (2000) 113-119.

[17] C. Kaya, B.E. Ak, D. Higss, Response of salt-stressed strawberry plants to supplementary calcium nitrate and/or potassium nitrate. J. Plant Nutr. 26 (2003) 543-560.

[18] S. Agarwal, V. Pandey, Antioxidant enzyme response to $\mathrm{NaCl}$ stress in Cassia angustifolia. Biol. Planta. 48(4) (2004) 555-560.

[19] R. Angelini, F. Manes, R. Federico, Spatial a functional correlation between daimine- oxsidase and peroxidase activities and their dependence upon defilation and wounding in chick-pea. Planta. 182 (1990) 89-96.

[20] Y. Gong, et al., Antioxidant system level in 'Braeburn' apple is related to its browning disorder. Botan. Bull. Acad. Sinica, 42 (2001) 259-264.

[21] R.Y. Yordanova, K.N. Christov, L.P. Popova, Antioxidative enzymes in barley plants subjected to soil flooding. Environ. Exper. Bot. 51 (2004) 93-101.

[22] J.M. Bremner, Nitrogen-total, in: D.L. Sparks (Ed.), Methods of Soil Analysis. Part III. Chemical Methods, 2nd ed. Soil Science Society of America, Madison, WI, USA, 1996, pp. $1085-1122$.

[23] D. Mertens, Plants preparation of laboratory sample, in: W. Horwitz, G.W. Latimer (Eds.), Official Methods of Analysis, 18th ed. Gaithersburg, MD, USA: AOAC, (2005) pp. 1-2.

[24] D. Mertens, Metal in plants and pet foods, in: W. Horwitz, G.W. Latimer (Eds.), Official Methods of Analysis. 18th ed. Gaithersburg, MD, USA: AOAC, (2005) pp. 3-4.

[25] D. I. Leskovar, D.J. Cantliffe, Pepper Seedling Growth Response to Drought Stress and Exogenous Abscisic Acid. J. Amer. Soc. Hort. Sci. 117(3) (1992) 389-393.

[26] F.A. Showemimo, J.D. Olarewaju, Drought Tolerance Indices in Sweet Pepper (Capsicum annuum L.). International Journal of Plant Breeding and Genetics. 1 (2007) 29-33.

[27] S. Mardani et al., Physiological responses of pepper plant (Capsicum annum L.) to drought stress. J. Plant Nutr. 40(10) (2017) 1453-1464.

[28] O.A. Kireççi, The effects of some synthetic hormons (gibberellic acid, spermine spermidine, putrescine) on basil (Ocimum basilicum) plants on its morphological characters and the quality of volatile oil. Master Thesis. University of Kahramanmaraş Sütçü İmam, Institute of Natural and Applied Sciences, Department of Biology (2006).

[29] R. Alcazar et al., Polyamine metabolic canalization in response to drought stress in Arabidopsis and the resurrection plant Craterostigma plantagineum. Plant Sign. and Behv. 6 (2011) 243250.

[30] A.I. Alet et al., New insights into the role of spermine in Arabidopsis thaliana under long term salt stress. Plant Sci. 182 (2012) 94-100.

[31] G. Costa, N. Bagni, Effects of polyamines on fruit-set of apple. Hort. Sc. 18(1) (1983) 59-61.

[32] N. Bagni, The function and metabolism of polyamines in plant. Acta Hort. 179 (1986) 95-103.

[33] M. Gallardo et al., The alleviation of thermoinhibition in chick-pea seeds by putrescine involves the ethylene pathway. Australian Journal of Plant Physiology. 23 (1996) 479-487. 
[34] A.W. Galston, R. Kaur-Sawhney, Polyamines in plant physiology. Plant Physiol. 94 (1990) 406-410.

[35] A. Kumar et al., Recent advances in polyamine research. Trends Plant Sci. 2 (1997) 124-130.

[36] R. Walden, A.Cordeiro, A.F. Tiburcio, Polyamines: small molecules triggering pathways in plant growth and development. Plant physiology.113(4) (1997) 1009.

[37] R.L. Malmberg et al., Molecular genetic analyses of plant polyamines. Critical Rev. Plant Sci. 17 (1998) 199-224.

[38] A. Bouchereau et al., Polyamines and environmental cahllenges: recent development. Plant Sci. 140 ( 1999) 103-125.

[39] N. Bagni, A. Tassoni, Bioseyntesis, oxidation and aliphatic polyamines in higher plants. Amino Acids. 20 (2001) 301-317.

[40] R. Alcazar et al., Involvement of polyamines in plant response to abiotic stress. Biotec. Lett. 28 (2006) 1867-1876.

[41] T. Kusano et al., Polyamines: essential factors for growth and survival. Planta. 228 (2008) 367381.

[42] R.K. Basra et al., Are polyamines involved in the heatshock protection of mung bean seedlings? Bot. Bull. Acad. Sin. 38 (1997) 165-169.

[43] H. Nayyar, S. Chander, Protective effects of polyamines against oxidative stress induced by water and cold stress in chickpea. J. Agron. Crop Sci. 190 (2004) 355-365.

[44] J.C. Yang et al., Remobilization of carbon reserves is improved by controlled soil-drying during grain filling of wheat. Crop Sci. 40 (2000) 1645-1655.

[45] Q. Zhou, B. Yu, Changes in content of free, conjugated and bound polyamines and osmotic adjustment in adaption of vetiver grass to water deficit. Plant Physiol. Biochem. 48 (2010) 417 425.

[46] R. Dolferus, To grow or not to grow: a stressful decision for plants. Plant Sci. 2229 (2014) 247261.

[47] Z. Li et al., Polamine regulates tolerance to water stress in leaves of white clover associated with antioxidant defence and dehydrin genes via involvement in calcium messenger system and hydrogen peroxide signaling. Front. Physiol. 6(280) (2015).

[48] W. Tang, R.J. Newton, Polyamines reduce salt-induced oxidative damage by increasing the activities of antioxidant enzymes and decreasing lipid peroxidation in Virginia pine. Plant Growth Regul. 46 (2005) 31-43.

[49] J.C. Yiu et al., Exogenous putrescine reduces flooding- induced oxidative damage by increasing the antioxidant properties of Welsh onion. Scientia Horticulturae. 120 (2009) 306-314.

[50] W. Zhang et al., Polyamines enhance chilling tolerance of cucumber (Cucumis sativus L.) thought modulating antioxidative system. Sci. Hotic. 122 (2009) 200-208.

[51] H. Shi, T. Ye, Z. Chan, Comperative protemic and physiological analyses reveal the protective effect of exogenous polyamines in te Bermuda grass (Cynodon dactylon) response to salt and drought stresses. J. Prote. Res. 12 (2013) 4807-4829.

[52] R. Minocha, R. Majumdar, S.C. Minocha, Polyamines and abiotic stress in plants: a complex relationship. Front. Plant Sci. 5(175) (2014).

[53] P. Valentovič et al., Effect of osmotic stress on compatible solutes content, membrane stability and water relations in two maize cultivars. Plant Soil Environ. 52(4) (2006) 184. 
[54] S. Hayat et al., Role of proline under changing environments: a review. Plant Sig. Behv. 7(11) (2012) 1456-1466.

[55] J. Krasensky, C. Jonak, Drought, salt and temperature stress-induced metabolic rearrangements and regulatory networks. J. Exp. Bot. 63(4) (2012) 1593-1608.

[56] I.U. Khan et al., Comparative diagnosis of typhoid fever by polymerase chain reaction and widal test in Southern Districts (Bannu, Lakki Marwat and KI Khan) of Khyber Pakhtunkhwa, Pakistan. Acta Sci. Malaysia. 1(2) (2017) 12-15.

[57] J.C. Yiu et al., Waterlogging tolerance of welsh onion (Allium fistulosum L.) enhanced by exogenous spermidine and spermine. Plant Physiol. Biochem. 47 (2009) 710-716.

[58] M.K. Nikolaeva et al., Effect of drought on chlorophyll content and antioxidant enzyme activities in leaves of three wheat cultivars varying in productivity. Russian J. Plant Physiol. 57(1) (2010) 87-95.

[59] E. Sanchez-Rodriguez et al., Genotypic differences in some physiological parameters symptomatic for oxidative stress under moderate drought in tomato plants. Plant Science. 178 (2010) 30-40.

[60] T. Kabay, C. Erdinç. S. Sensoy, Effects of drought stress on plant growth parameters, membrane damage index and nutrient content In common bean genotypes. J. Animal and Plant Sci. 27 (3) (2017) 940-952.

[61] Z. Li et al., Exogenous spermidine improves seed germination of white clover under water stress via involvement in starch metabolism, antioxidant defenses and relevant gene expression. Molecules. 19 (2014a) 18003-18024.

[62] Z. Li et al., Exogenous spermidine improves water stress tolerance of white clover (Trifolium repens L.) involved in antioxidant defense, gene expression and proline metabolism. Plant Omics. 7 (2014) 517-526.

[63] C.J. Liu et al, Effects of different types of polyamine on growth, physiological and biochemical nature of lettuce under drought stress. IOP Conf. Series: Earth and Environmental Science 185 (2018) 012010.

[64] S. Verma, S.N. Mishra, Putrescine alleviation of growth in salt stressed Brassica juncea by inducing antioxidative defense system. J. Plant Physiol. 162 (2005) 669-677.

[65] M. Farooq et al., Plant drought stress: effects, mecanisms and management. Agron. Sus. Develop. 29 (2009) 185-212.

[66] M.H. Farahi, A.A. Jahroomi, Effect of pre-harvest foliar application of polyamines and calcium sulfate on vegetative characteristics and mineral nutrient uptake in Rosa hybrida. J. Ornamental Plants. 8(4) (2018) 241-253.

[67] A.A. Youssef, M.H. Mahgoub, I.M. Talaat, Physiological and biochemical aspects of Matthiola incana L. plants under the effect of putrescine and kinetin treatments. J. Appl. Sci. 19 (9B) (2004) 492-510.

[68] H. Marshall et al., The use of trimethylamine N-oxide as a primary precipitating agent and related methylamine osmolytes as cryoprotective agents for macromolecular crystallography. Acta Cryst. (2012). D68, 69-81.

[69] B.E. Algul, F.E. Tekintas, G.G. Dalkilic, The Usage of Plant Growth Regulators and Hormone Biosynthesis Booster Applications. Journal of Adnan Menderes University Agricultural Faculty (2016) 13(2): $87-95$. 
[70] E. Sánchezrodríguez, L. Romero, J.M. Ruiz, Accumulation of free polyamines enhances the antioxidant response in fruits of grafted tomato plants under water stress. J. Plant Physiol. 190 (2016) 72-78.

[71] H. Mohammadi, M. Ghorbanpour, M. Brestic, Exogenous putrescine changes redox regulations and essential oil constituents in field-grown Thymus vulgaris L. under well-watered and drought stress conditions. Ind. Crops Prod. 122 (2018) 119-132.

[72] D. Chen et al., Polyamine Function in Plants: Metabolism, Regulation on Development, and Roles in Abiotic Stress Responses. Front. Plant Sci. 9 (2019) 1945. 